\title{
KECERNAAN PROTEIN DAN RETENSI NITROGEN PADA DOMBA YANG DIBERI SILASE PAKAN KOMPLIT BERBAHAN ECENG GONDOK DENGAN STARTER Lactobacillus plantarum Protein Digestibilty and Nitrogen Retention on Sheep Fed with Complete Feed Silage from Water Hyacinth with Starter Lactobacillus plantarum
}

\author{
L. Hanun, A. Muktiani, dan L. K. Nuswantara \\ Fakultas Peternakan dan Pertanian Universitas Diponegoro \\ Jl. Prof. H. Soedarto, SH, Tembalang, Semarang 50275 \\ E-mail: anismuktiani@gmail.com
}

\begin{abstract}
This study aimed to determine the use of L. plantarum starter on a complete ration silage made from water hyacinth on protein digestibility and nitrogen retention. This study use fifteen rams (12 month old with anaverage body weight of $19 \pm 3.98 \mathrm{~kg}$ ). The sheeps were randomly devided into 3 treatment and 5 replications. $T 1=$ elephant grass and concentrate, $T 2=$ complete feed silage contain water hyacinth without addition of $L$. plantarum starter. and T3 = complete feed silage contain water hyacinth addition with $L$. plantarum starter. Feed structured treatment isoenergy and isoprotein (PK $13 \%$ and 65\% $T D N)$. The result showed that the nitrogen retention, protein consumption, and protein digestibility was not significantly different among treatments. Protein consumption of treatment T1, T2 and T3 was 87,97, 108,00, 94,17 g/day, protein digestibility 77,29, 75,00, 77,07g/day and nitrogen retention was 8,82;10,47; and 8,29 g. and In conclusion, Complete feed silage water hyacinth can replace the fattening rations in sheeps.
\end{abstract}

Key word : silage, L. plantarum, nitrogen retention, digestibility protein, sheep.

\begin{abstract}
ABSTRAK
Penelitian ini bertujuan untuk mengetahui pengaruh penggunaan starter L. plantarum pada silase pakan komplit berbahan eceng gondok terhadap kecernaan protein dan retensi nitrogen. Penelitian ini menggunakan lima belas ekor domba jantan berumur 12 bulan dengan berat badan rata-rata $19 \pm 3,98 \mathrm{~kg}$. Rancangan percobaan yang digunakan adalah rancangan acak lengkap dengan 3 perlakuan dan 5 ulangan, yaitu $\mathrm{T} 1=$ rumput gajah dan konsentrat, $\mathrm{T} 2=$ silase pakan komplit berbahan eceng gondok tanpa penambahan starter $L$. plantarum, dan $\mathrm{T} 3$ = silase pakan komplit berbahan eceng gondok dengan penambahan starter L. plantarum. Pakan perlakuan disusun isoenergi dan isoprotein (PK 13\% dan TDN $65 \%$ ). Hasil penelitian menunjukkan bahwa konsumsi protein, kecernaan protein dan retensi nitrogen tidak berbeda nyata antar perlakuan. Konsumsi protein masing-masing perlakuan T1, T2, dan T3 adalah adalah 87,97, 108,00, 94,17 g/hari dan kecernaan protein masing-masing 77,29, 75,00, 77,07 g/hari, sedangkan retensi nitrogen adalah sebesar 8,82; 10,47 dan 8,29 g/hari. Kesimpulan hasil penelitian ini adalah bahwa silase pakan komplit berbahan eceng gondok dapat menggantikan ransum penggemukan pada domba.
\end{abstract}

Kata kunci : silase, L. plantarum, kecernaan protein, retensi nitrogen, domba 


\section{PENDAHULUAN}

Kebutuhan masyarakat akan daging domba tidak pernah surut. Pemeliharaan ternak domba di Indonesia masih didominasi oleh peternakan skala rakyat karena ternak domba mudah pemeliharannya dan cukup menguntungkan. Namun, dalam manajemen pemeliharaannya masih bersifat tradisional, misalnya dalam pemberian pakan masih belum memperhatikan kesesuaian dengan kebutuhan ternak.

Indonesia merupakan negara tropis yang memiliki 2 musim yaitu musim kemarau dan musim penghujan. Perbedaan musim ini mempengaruhi ketersediaan pakan untuk ternak, khususnya dimusim kemarau pakan ternak sulit didapat. Salah satu alternatif yang dapat digunakan untuk menyediakan pakan adalah eceng gondok yang dikenal sebagai gulma. Pertumbuhan eceng gondok yang sangat cepat dikhawatirkan dapat mengganggu fungsi perairan umum. Eceng gondok segar mempunyai kadar air (KA) sebesar 94,09\%, dan dalam $100 \%$ bahan kering (BK) mempunyai $18 \%$ abu, protein kasar (PK) $11,9 \%$, serat kasar (SK) 37,1\%, lemak kasar (LK) 2,4\% dan 30.6\% bahan ekstrak tanpa nitrogen (BETN). Dilihat dari kandungan nutriennya, eceng gondok mempunyai kualitas yang baik sebagai pengganti pakan hijauan (Muktiani, 2013 ${ }^{\mathrm{a}}$ ).

Eceng gondok yang dibuat menjadi silase pakan komplit perlu ditambahkan dengan bahan-bahan penyusun konsentrat yang berfunggsi sebagai penyerap air eceng gondok sehingga mencapai kadar air yang ideal. Proses pembuatan silase pakan komplit dapat dipercepat dengan menambahkan starter bakteri asam laktat atau dengan starter $L$. plantarum. Starter $L$. Plantarum merupakan bakteri asam laktat yang besifat homofermentatif (hanya membentuk asam laktat dari gula), jika asam laktat semakin cepat terbentuk maka $\mathrm{pH}$ silase akan cepat turun, sehingga silase akan menjadi lebih awet dan tahan lama (Muktiani et al., 2013 ${ }^{\mathrm{b}}$ ).

Salah satu kebutuhan nutrien pada ternak yang perlu diperhatikan adalah protein. Secara biologis kualitas pakan pada ruminansia dipengaruhi oleh ketersediaan protein pakan yang mampu memberikan kontribusi pada perkembangbiakan mikrobia dalam rumen dan mampu mensuplai protein pakan di intestinum. Proses pemanfaatan protein salah satunya dipengaruhi oleh jumlah protein yang dikonsumsi. Jumlah konsumsi protein dipengaruhi oleh level pemberian pakan. Peningkatan konsumsi protein juga dipengaruhi oleh kandungan protein dalam pakan yaitu semakin tinggi kandungan protein semakin banyak pula protein yang terkonsumsi. Sumber utama protein yang masuk kesaluran pencernaan pasca rumen adalah protein pakan bebas perombakan dan protein mikroba yang disintesis dalam rumen. jumlah retensi nitrogen menunjukkan banyaknya nitrogen yang tertahan di dalam tubuh ternak karena dimanfaatkan oleh ternak tersebut. Nilai kecernaan protein kasar dalam suatu ransum juga sangat menentukan nilai retensi nitrogen ransum. Retensi nitrogen selain digunakan untuk menilai kualitas protein juga dapat digunakan untuk menentukn kualitas bahan pakan (Puastuti et al., 2012).

Penelitian ini bertujuan untuk meningkatkan pemanfaatan protein ransum pada domba dengan penambahan starter $L$. plantarum pada proses pembuatan silase pakan komplit berbahan eceng gondok dengan melihat retensi nitrogen dan kecernaan protein. Manfaat penelitian ini diharapkan dapat memberikan informasi 
mengenai pakan alternatif berupa silase pakan komplit berbahan eceng gondok yang menggunakan starter L. plantarum berdasarkan kualitas proteinnya.

Hipotesis penelitian adalah penambahan starter L. Plantarum pada proses pembuatan silase pakan komplit berbahan eceng gondok berpengaruh terhadap kecernaan protein dan retensi nitrogen.

\section{MATERI DAN METODE}

Penelitian dilaksanakan pada bulan November 2013 sampai Februari 2014, di kandang dan di Laboratorium Ilmu Nutrisi dan Pakan Fakultas Peternakan dan Pertanian Universitas Diponegoro, Semarang. Materi yang digunakan untuk penelitian adalah domba lokal jantan sebanyak 15 ekor dengan umur 12 bulan dengan bobot badan rata-rata $19 \pm 3,98 \mathrm{~kg}$. Domba dibagi secara acak menjadi 3 perlakuan dan 5 ulangan, dan diberi ransum perlakuan berupa konsentrat dan rumput gajah (T1), silase pakan komplit berbahan eceng gondok tanpa starter $L$. Plantarum (T2), dan silase pakan komplit berbahan eceng gondok dengan penambahan starter

\section{Plantarum (T3).}

Pengujian pakan secara in vivo dilakukan dengan 3 tahapan yaitu tahap persiapan meliputi tahap mempersiapkan kandang untuk pemeliharaan, mengadakan bahan pakan yang digunakan untuk menyusun pakan perlakuan, dan analisis proksimat bahan pakan. Kandungan nutrien ransum perlakuan dapat dilihat pada Tabel 1.

Tahap pelaksanaan dilakukan selama 12 minggu yang terdiri dari 2 minggu adaptasi ransum dan 10 minggu pengambilan data retensi nitrogen, konsumsi protein dan kecernaan protein. Domba ditempatkan pada kandang individu yang dilengkapi dengan palung pakan. Pada tahap adaptasi domba diberi pakan berupa rumput saja kemudian semakin hari dikurangi proporsinya dengan ditambah pakan perlakuan. Pakan perlakuan dan air minum diberikan secara ad libitum. Pemberian rumput gajah pada perlakuan kontrol diberikan minimal selang satu jam setelah pemberian konsentrat. Penimbangan sisa pakan perlakuan dilakukan keesokan harinya sebelum memberikan pakan perlakuan pada pagi hari. Domba ditimbang 2 minggu sekali menggunakan timbangan berkapasitas 50 $\mathrm{kg}$ dengan ketelitian 0,01 kg, sedangkan pakan ditimbang dengan timbangan dengan kapasitas $5 \mathrm{~kg}$ dengan ketelitian 0,01 kg.

Tabel 1. Kandungan Nutrisi Ransum Perlakuan

\begin{tabular}{lrrr}
\hline \multirow{2}{*}{ Kadar Nutrien } & & Perlakuan & T3 \\
\cline { 2 - 4 } & T1 & T2 & 30,66 \\
Bahan Kering & $-----\%, 68$ & 30,15 & 13,53 \\
Protein Kasar & 12,97 & 13,31 & 25,15 \\
Serat Kasar & 25,14 & 24,74 & 66,22 \\
TDN & 64,82 & 65,12 & 5,60 \\
Lemak Kasar & 6,11 & 5,51 & 11,40 \\
Abu & 11,51 & 11,21 & 44,32 \\
BETN & 44,27 & 45,27 & \\
\hline
\end{tabular}

Keterangan: $\mathrm{TDN}=$ total digestible nutrient, $\mathrm{BETN}=$ bahan ekstrak tanpa nitrogen 
Pengukuran kecernaan protein dilakukan dengan metode total koleksi. Feses dan urine dikoleksi setiap hari dan disemprot menggunakan $\mathrm{H}_{2} \mathrm{SO}_{4} 3 \%$ setiap 3 jam sekali. Koleksi feses dilakukan selama satu minggu berturut-turut, berat basah feses dicatat, kemudian feses dikeringkan di bawah sinar matahari, dihomogenisasikan dan diambil sampel $10 \%$. Feses dibersihkan dari bulu dan kotoran lain selanjutnya dianalisis kadar bahan kering dan kadar protein kasarnya.

Konsumsi protein dihitung dengan mengalikan presentase kadar protein pakan dengan konsumsi bahan kering pakan. Kecernaan protein diukur sebagai selisih antara protein yang dikonsumsi dengan protein yang dikeluarkan melalui feses. Konsumsi protein dan kecernaan protein dianalisis di Laboratorium Nutrisi dan Pakan. Jumlah retensi nitrogen menunjukkan banyaknya nitrogen yang tertahan di dalam tubuh ternak. Retensi nitrogen dihitung dengan menggunakan rumus:

$$
\begin{gathered}
\text { Retensi Nitrogen }(\mathrm{g})=\text { Konsumsi } \mathrm{N}-(\mathrm{N} \\
\text { Urin }+\mathrm{N} \text { Feses })
\end{gathered}
$$

Nilai tengah hasil pengamatan diuji menggunakan analisis ANOVA dan apabila terdapat pengaruh perlakuan yang nyata $(\mathrm{P}<0,05)$ dilanjutakan dengan Duncan Multiple Range Test pada taraf 5\% (Steel dan Torrie, 1995).

\section{HASIL DAN PEMBAHASAN}

Hasil pengaruh penggunaan silase pakan komplit berbahan enceng gondok terhadap konsumsi, kecernaan protein pakan dan retensi nitrogen tercantum pada tabel 2.

Tabel 2. Kecernaan Protein Pakan dan Retensi Nitrogen pada Domba.

\begin{tabular}{llll}
\hline \hline \multirow{2}{*}{ Parameter } & \multicolumn{3}{c}{ Perlakuan } \\
\cline { 2 - 4 } & \multicolumn{1}{c}{$\mathrm{T} 1$} & \multicolumn{1}{c}{$\mathrm{T} 2$} & $\mathrm{~T} 3$ \\
\hline Konsumsi Protein (g/hari) & $87,97 \pm 14,41$ & $108,00 \pm 12,50$ & $94,17 \pm 13,58$ \\
Ekskresi N via Feses (g/hari) & $3,25 \pm 0,09^{\mathrm{a}}$ & $4,33 \pm 0,05^{\mathrm{b}}$ & $3,50 \pm 0,09^{\mathrm{b}}$ \\
Kecernaan Protein (\%) & $77,29 \pm 4,64$ & $75,00 \pm 1,03$ & $77,07 \pm 4,92$ \\
Ekskresi N via Urin (g/hari) & $2,00 \pm 0,20$ & $2,48 \pm 0,17$ & $3,27 \pm 0,21$ \\
Retensi Nitrogen (g) & $8,82 \pm 1,73$ & $10,47 \pm 1,43$ & $8,29 \pm 2,24$ \\
\hline
\end{tabular}

a, b superskrip dengan huruf kecil yang berbeda pada baris yang sama menunjukkan perbedaan yang nyata $(p>0,05)$.

\section{Konsumsi Protein}

Penggunaan starter L. Plantarum pada proses pembuatan silase pakan komplit berbahan enceng gondok ini berpengaruh tidak nyata terhadap konsumsi protein $(\mathrm{P}>0,05)$. Perlakuan yang diberikan pada domba menghasilkan konsumsi protein yaitu 87,97-107,14 g/hari. Hasil penelitian ini lebih tinggi dari yang dilaporkan (Rimbawanto dan Irianti, 2000) yaitu konsumsi protein domba yang diberi pakan berupa kulit biji kedelai sebagai pengganti jagung dalam ransum sebesar 68,02-94,33 g/hari, namun lebih rendah dibandingkan hasil penelitian Purbowati et al. (2009) bahwa konsumsi protein pada domba lokal jantan yang diberi pellet pakankomplit dari berbagai limbah pertanian dan agroindustri berkisar antara 130,08-153,18 g/hari.

Konsumsi protein yang tidak berbeda nyata antar perlakuan kemungkinan disebabkan oleh palatabilitas pakan. Domba ternyata menyukai silase pakan komplit 
berbahan eceng gondok (T2 dan T3), sehingga jumlah silase pakan komplit yang dikonsumsi bisa mengimbangi pakan konvensional berupa rumput gajah dan konsentrat (T1). Bau segar yang khas pada silase serta kadar air yang cukup tinggi sekitar 60-70\% menyebabkan domba menyukai silase pakan komplit. Dalam hal ini penambahan L. Plantarum pada pembuatan silase (T3) tidak mempengaruhi tingkat konsumsi dibandingkan dengan tanpa L. Plantarum (T2), hal ini kemungkinan disebabkan penambahan $L$. Plantarum tidak mengubah tekstur dan bau pakan sehingga menghasilkan palatabilitas yang sama. Selain itu konsumsi protein yang tidak berbeda nyata juga disebabkan oleh kandungan protein pakan perlakuan yang relative sama. Hal ini sesuai dengan pendapat Tillman et al. (1998) bahwa selain konsumsi bahan kering, kandungan nutrien pakan juga berpengaruh terhadap tingkat konsumsi nutrien.

\section{Kecernaan Protein}

Penggunanan Starter L. Plantarum pada silase pakan komplit berbahan eceng gondok pada penelitian ini tidak berpengaruh nyata terhadap kecernan protein $(\mathrm{P}>0,05)$. Kecernaan protein pada perlakuan T1, T2, T3 adalah sebesar 76,27$78,59 \%$. Hasil penelitian ini relative sama dengan hasil penelitian Ndaru et al. (2014) bahwa kecernaan protein pada suplementasi berbagai level daun ketela pohon terhadap produktifitas domba ekor gemuk yang diberi pakan basal jerami jagung yaitu berkisar antara 70,73- 78,61\%.

Kecernaan protein yang tidak berbeda pada penelitian ini diduga karena kandungan protein pakan yang relative sama, sehingga akan menghasilkan pertumbuhan bakteri rumen yang tidak berbeda. Hal ini sesuai dengan pendapat
Prihatini et al. (2011) bahwa faktor yang berpengaruh pada kecernaan adalah ketersediaan nutrien sebagai makanan untuk pertumbuhan mikroba. Meskipun potensi pakan untuk dicerna tinggi tetapi apabila lingkungan rumen tidak mendukung untuk aktivitas fermentasi mikrobia rumen maka kecernaan akan menjadi rendah.

Menurut Arora (1995) daya cerna suatu bahan pakan dipengaruhi oleh laju pakan dalam saluran pencernaan, bentuk fisik pakan dan komposisi pakan. Dalam hal ini kecernaan perlakuan T1, T2 dan T3 tidak berbeda nyata diduga karena laju pakan dalam saluran pencernaan yang tidak berbeda. Komposisi pakan yang relative sama yaitu terdiri dari hijauan dan konsentrat meskipun pada perlakuan $\mathrm{T} 2$ dan T3 kemudian dibuat silase menyebabkan laju pakan yang sama di dalam saluran pencernaan. Menurut Prasetiyono et al., (2007), kecernaan pakan yang tinggi mengindikasi bahwa laju pengosongon isi rumen berlangsung cepat. Soebarinoto et al. (1991) dan Rianto et al. (2006) menyatakan bahwa tingkat konsumsi juga mempengaruhi kecernaan, konsumsi pakan yang tinggi menyebabkan laju digesta didalam saluran pencernaan semakin tinggi, sehingga waktu yang tersedia bagi enzim untuk memecah nutrien menjadi terbatas dan pada akhirnya kecernaan pakan menjadi menurun. Perlakuan pada penelitian ini menghasilkan tingkat konsumsi yang tidak berbeda, dengan demikian menghasilkan tingkat kecernaan yang tidak berbeda pula. Menurut Tillman et al. (1998) peningkatan konsumsi dapat menurunkan kecernaan, terkait dengan laju alir pakan dalam saluran pencernaan yang semakin cepat, akibatnya lama waktu tinggal digesta dalam rumen berkurang sehingga proses pencernaan tidak optmal. 


\section{Retensi Nitrogen}

Penggunanan Starter L. Plantarum pada silase pakan komplit berbahan eceng gondok pada penelitian ini tidak berpengaruh nyata terhadap retensi nitrogen ( $\mathrm{P}>0,05)$ meskipun menunjukkan perbedaan yang nyata pada eksresi $\mathrm{N}$ feses. Hasil penelitian retensi $\mathrm{N}$ pada perlakuan T1, T2 dan T3 berkisar 8,29-10,47 gram. Menurut Puastuti et al., (2012) bahwa nilai kecernaan protein kasar dalam suatu ransum juga sangat menentukan nilai retensi nitrogen ransum. Kecernaan protein pada penelitian ini tidak berbeda nyata, sehingga menghasilkan rentensi $\mathrm{N}$ yang tidak berbeda nyata pula. Prayuwidayati dan Widodo (2007) menyatakan bahwa jumlah retensi nitrogen menunjukkan banyaknya nitrogen yang tertahan di dalam tubuh ternak karena dimanfaatkan oleh ternak tersebut. Retensi nitrogen selain digunakan untuk menilai kualitas protein juga dapat digunakan untuk menentukan kualitas bahan pakan. Tillman et al. (1998) menyatakan bahwa nitrogen yang diretensi merupakan bagian nitrogen dari pakan yang tidak diekskresikan dalam feses dan urin.

Nilai retensi nitrogen antar perlakuan menghasilkan nilai retensi $\mathrm{N}$ yang positif. Menurut Puastuti et al. (2012) retensi nitrogen bernilai positif apabila jumlah nitrogen yang keluar melalui urin dan feses lebih sedikit dari yang dikonsumsi, dalam hal ini terjadi deposisi atau penggunaan protein pakan untuk kebutuhan produksi. Hasil penelitian ini menunjukkan adanya sejumlah nitrogen yang tersimpan dalam tubuh ternak yang digunakan untuk pertambahan bobot badan pada domba perlakuan.

\section{KESIMPULAN}

Pemberian silase pakan komplit berbahan eceng gondok tanpa starter maupun dengan starter L. Plantarum menghasilkan kecernaan protein dan retensi nitrogen yang sama dengan pakan konvensional.

\section{DAFTAR PUSTAKA}

Arora, S.P. 1995. Pencernaan Mikroba dan Ruminansia. Gadjah Mada University Press, Yogyakarta. (Diterjemahkan oleh R. Murwani).

Muktiani, A. 2013 ${ }^{\mathrm{a}}$. Peningkatan kualitas pakan ternak berbahan eceng gondok. Prosiding. Workshop Penyelamatan ekosistem Danau Rawa Pening, Semarang. 13 Juni 2013. Kementrian Lingkungan Hidup bekerjasama dengan Universitas Diponegoro. 65-72.

Muktiani, A. B. Utomo, K. G. Wiryawan, dan E. Pangestu. 2013 . Pemanfaatan Eceng Gondok dalam Pembuatan Silase Complete feed dan Suplementasi Zink Organik untuk Meningkatkan Produktivitas Peternakan Rakyat. Laporan Penelitian KKP3N. Lembaga Penelitian dan Pengabdian kepada Masyarakat. Universitas Diponegoro, Semarang.

Ndaru P. H., Kusmartono dan S. Chuzaemi. 2014. Pengaruh suplementasi berbagai level daun ketela pohon (manihot utilissima. Pohl) terhadap produktivitas domba ekor gemuk yang diberi pakan basal jerami jagung (zea mays). Jurnal Ilmu-Ilmu Peternakan 24 (1):9-25.

Prasetiyono, B.W.H.E., Suryahadi, T. Toharmat dan R. Syarief. 2007. Strategi suplementasi protein ransum sapi potong berbasis jerami dan dedak padi. Media Peternakan. 30 : 207-217. 
Prayuwidayati, M.M. dan Y. Widodo. 2007. Penggunaan bagas tebu teramoniasi dan terfermentasi dalam ransum ternak domba. Majalah Ilmu Peternakan. 10 : 1-14

Prihatini, I., Soebarinoto., S. Chuzaemi dan M. Winugroho. 2011. Karakteristik nutrisi dan degradasi jerami padi fermentasi oleh inokulum lignolitik TliD dan BopR. Animal Production. 11 (1): $1-7$

Puastuti, W., D. Yulistiani, dan I. W. Mathius. 2012. Respon Fermentasi Rumen dan Retensi Nitrogen dari Domba yang Diberi Protein Tahan Degradasi dala Rumen. J. Ilmu Ternak dan Veteriner 17 (1): 67-72.

Purbowati. E., C. I. Sutrisno, E., Baliarti dan S.P.S. Budhi. 2009. Penampilan domba lokal jantan dengan pakan komplit dari berbagai limbah pertanian dan agroindustri. Pros. Seminar Nasional Kebangkitan Peternakan, Semarang. 20 Mei 2009. 130-138.

Rianto, E., E. Haryono dan C.M. Lestari. 2006. Produktivitas domba ekor tipis jantan yang diberi pollard dengan aras berbeda. Prosiding Seminar Nasional Teknologi Peternakan dan Veteriner. Puslitbang Peternakan, Bogor. Hal: 431-439.

Rimbawanto E. A dan N. Iriyanti. 2000. Pengaruh penggunanan kulit biji kedelai sebagai pengganti jagung dalam ransum terhadap kecernaan energi, protein dan kinerja domba. Animal Production. Vol. 2 (2) : 98 103.

Soebarinoto., S. Chuzaemi dan Marshudi. 1991. Ilmu Gizi Ruminansia. Jurusan Nutrisi dan Makanan
Ternak Universitas Brawijaya, Malang.

Tillman, A. D., H. Hartadi., S. Reksohadiprodjo, S. Prawirokusumo dan S. Lebdosoekojo. 1998. Ilmu Makanan Ternak Dasar. Edisi ke-5. Gadjah Mada University Press, Yogyakarta. 